\title{
Ergen bir Olguda Diazepam ile Düzelen Katatoni; Olgu Sunumu
}

\section{Diazepam For Catatonia in an Adolescent; A Case Report}

\section{Hasan Bozkurt ${ }^{1}$, Seda Tabak', Serkan Şahin ${ }^{1}$}

Tokat Gaziosmanpaşa Üniversitesi Tıp Fakültesi, Çocuk ve Ergen Ruh Sağlığı ve Hastalıkları A.D. Tokat

\section{ÖZET}

Yazında katatoni tedavisinde lorazepam ve elektrokonvulsif terapinin (EKT) etkinliği ile ilgili çalışmalar yer almaktadır. Bu yazıda katatoni tablosu nedeniyle servisimize yatırılıp diazepam tedavisi ile katatoni tablosu düzelen 14 yaşında bir kız olgunun klinik özellikleri ve katatoni tablosunun ayırıcı tanısı literatür eşliğinde tartışımıştır.

Anahtar kelimeler: Katatoni, diazepam, ergen

\section{ABSTRACT}

There have been studies demonstrating the efficacy of lorazepam and electroconvulsive therapy in the treatment of catatonia. Here we present a 14-year-old adolescent case hospitalized with a diagnosis of catatonia and treated with diazepam. Clinical features and possible differential diagnosis will be discussed in the light of literature findings.

Key words: Catatonia, diazepam, adolescent
Corresponding Author: Hasan Bozkurt

Address: Tokat Gaziosmanpaşa Üniversitesi Tıp Fakültesi, Çocuk ve Ergen Ruh Sağlığı ve Hastalıkları A.D. Tokat

E-mail: drhasan33@gmail.com
Başvuru Tarihi/Received: 25-01-2016

Kabul Tarihi/Accepted: 28-02-2016 


\section{GIRIŞ}

Katatoni, temel belirti ve bulguları mutizm, postür alma, stupor, motor rijidite, aşırı uyarımışlık hali, yeme-içme reddi ve hipokinezi olan bir motor disregülasyon sendromudur.1 Katatoni DSM-5'te ayrı bir başlık olarak yer almıştır.2 Katatoni tablosu ve ayırıcı tanısı erişkin yaş grubundaki olgularda uzun yıllardır ilgi çeken bir konu olmasına rağmen çocuk ve ergen yaş grubunda bu alandaki farkındalığın düşük olduğu izlenmektedir. Çocuk ve ergenlerde katatoni tablosunun tanınması ve ayırıcı tanısının bilinmesi, yapılması gereken incelemeler ve tedavi protokolünün belirlenmesi açısından önemlidir.

Yazında katatoni tedavisinde lorazepam ve elektrokonvulsif terapinin (EKT) etkinliği ile ilgi-li çalışmalar yer almaktadır.3 Bu yazıda katatoni tablosu nedeniyle servisimize yatırılıp diazepam tedavisi ile katatoni tablosu düzelen 14 yaşında bir kız olgunun klinik özellikleri ve katatoni tablo-sunun ayırıcı tanısı tartışılmıştır.

\section{OLGU SUNUMU}

A, 14 yaşında kız çocuğu, 8. sınıfta okuyor, üç kardeşin en büyüğü, anne, baba ve kardeşleriyle yaşıyordu. Kliniğimize Çocuk Acil Birimi tarafından son üç gündür konuşmama, hareketsizlik, yeme ve içme reddi şikâyetleriyle konsulte edildi. Anne ve babasından alınan bilgiye göre son iki aydır A'da aşırı hareketlilik, gereğinden fazla konuşma, uyku ihtiyacında azalma ve sebepsiz gülmeler olduğu öğrenildi. Ailesi okul bitip tatil başladığı için A'nın bu belirtileri sergilediğini dü-şünerek herhangi bir psikiyatrik başvuruda bu-lunmadıklarını fakat üç gün önce hareketsizlik, uzun süre bir pozisyonda sabit oturma, yeme ve içmeyi reddetme, konuşmama ve altına idrar ka-çırma gibi şikâyetler olması üzerine hastanemiz Çocuk Acil birimine başvurmaya karar verdikle-rini ifade ettiler. Hastanın ruhsal durum muayenesinde görüşmeye isteksiz olduğu, soruların hiçbirine cevap vermediği, yattığı yerden kalkmak istemediği gözlendi. Duygulanımı kısıtlıydı. Oryantasyon, algı, bellek muayenesi yapılamadı. Konuşmadığı için düşünce içeriği değerlendirilemedi. Olgu sürekli olarak yatağında gözler açık şekilde postür değiştirmeden sırtüstü yatıyordu.

Anne ve babasının yönlendirmesi ile annesi eşliğinde tuvalete gidiyordu. Garip ağız ve el hareketleri şeklinde motor stereotipiler göze çarpıyordu. Katatoni tablosu düşünülen hastanın servise yatışı yapıldı. Yatış sonrası olgunun vital bulgu takibi, rutin kan tahlilleri, tiroid fonksiyon testleri, kreatinin kinaz (CK) düzeyi, tam idrar tetkiki, idrarda madde taraması, B12 ve folik asit düzeyi, anti-HBs, anti-HiV, HCV-RNA, VDRL, CRP, kan seruloplazmin düzeyi, kranial MR ve EEG değerlendirmeleri yapıldı. Olgunun kan tahlilleri, serum CK düzeyi, idrar tetkikleri, kranial MR ve EEG sonucu normal sınırlarda, nörolojik muayenesi, göz dibi normal olarak değerlendirildi. Bunun üzerine katatoni için lorazepam başlanmaya karar verildi fakat hasta ilaç içmeyi reddettiğinden ve lorazepamın parenteral formu da ülkemizde bulunmadığı için diazepam IV yolla $10 \mathrm{mg} /$ gün başlandı. Illk diazepam dozundan birkaç saat sonra hastanın annesi ve nöbetçi hemşire ile kendiliğinden konuşması oldu. Vital bulguları yatışı boyunca normal seyreden hastamızda dia-zepam dozu 15 mg/güne kadar arttırıldı. Takipte hasta tedavi ekibinin sorularına önce tek kelimeler sonra kısa cümleler ile cevap vermeye başladı. Gün içinde yatağında yatması azaldı ve kendi isteği ile serviste gezinmeye ve diğer hastaların yanında oturmaya başladı. İkinci günden itibaren yeme ve içmeye başladı. Doldurulan Klinik Global İzlenim Hastalık Şiddeti (CGI-SI) ve Klinik Global İzlenim Genel İyileşme (CGI-GI) 
ölçekleri-ne göre takipte olgunun CGI-SI puanı 6'dan 1'e düştü; CGI-GI puanı da 1 olarak değerlendirildi. Yatışının dördüncü gününde tüm belirtileri düzelen hasta diazepam oral 5 $\mathrm{mg} /$ gün alarak taburcu edildi. Bir hafta sonra yapılan poliklinik kontrolünde herhangi bir katatonik belirtiye rastlanmadı. Geçirilmiş katatoni tablosunun altta yatan bipolar bozukluğa (geçirilmiş manik epizod) bağı olduğu düşünülerek hastaya valproik asit 1000 $\mathrm{mg} / g u ̈ n$ eklendi. Rutin poliklinik kontrollerinde manik belirtileri tekrarlamayan ve ötimik olan hasta valproik asit tedavisi ile takip edilmektedir.

\section{TARTIŞMA}

Olgumuzda hareket etmeme, konuşmama, yeme içme reddi gibi tipik katatoni bulgularının hastanemize ilk başvuru sırasında bulunması katatoni tablosunu tanımamızı kolaylaştırmıştır. DSM-IV'te katatoni, şizofreninin bir alt tipi olarak belirtilmektedir. Ancak farklı tanı kategorisinde bulunan hastalıklarda da katatoni bir belirti olarak ortaya çıkabilmektedir. Özellikle son çalışmalarda altta yatan tanının sıklıkla duygudurum bozukluğu olduğu belirtilmektedir.4 Olgumuzda hastanemize ilk başvuru öncesi aileden alınan bilgiler doğrultusunda katatoni öncesi görülen aşırı hareketlilik, gereğinden fazla konuşma, uyku intiyacında azalma ve sebepsiz gülmeler gibi belirtiler muhtemel bir manik epizotu akla getirdiğinden olgumuzda düşünülen bipolar bozukluk tanısı bu yazın bilgisini desteklemektedir.

Olgumuz acile ilk başvurduğunda katatoni tablosu içinde olması ve ailesi tarafından katatoni öncesindeki manik belirtilerin ani olarak başladığının ifade edilmesi nedeniyle öncelikli olarak organisiteyi dışlamaya yönelik tetkikler yapılmıştır. Yazında birçok tıbbi ve nörolojik hastalığa bağlı olarak da katatoni tablosu gelişebileceği bildirilmektedir.5,6 Katatoni tablosu ile başvuran çocuk ve ergenlerde altta yatan tıbbi veya nörolojik hastalık sıklığı azımsanamayacak bir orandadır. ileriye dönük prevalans çalışmalarında psikiyatri kliniklerinde genel tıbbi bir duruma bağıı katatoni sıklığı \%20-25 oranında bulunmuştur.1 Kafa travması, epilepsi, metabolik ve endokrin bozukluklar, karaciğer yetmezliği, hepatik ensefalopati, sistemik lupus eritematozus, enfeksiyonlar (EbsteinBarr, hepatit C) ve çeşitli ilaçlara bağlı katatoni gelişebilir.7,8 Yine yaygın gelişimsel bozukluğu olan çocuklarda özellikle ergenlik döneminde katatoninin ortaya çıkabileceği bildirilmektedir.9,10 Olgumuzda yaygın gelişimsel bozukluk tanısını destekleyen bir belirti veya gelişim basamaklarında gecikme bulunmamaktadır. Diğer sistemik hastalıkları dışlamak için yapılan ayrıntılı tıbbi incelemelerde herhangi bir pozitif bulguya rastlanmamıştır. Non-konvulsif status epileptikusu ve ensefaliti dışlamak için yapılan EEG ve ayrıntılı nörolojik muayene normal sınırda olarak değerlendirilmiş, lökositoz saptanmamıştır.

Yazında özellikle duygu durum bozuklukları na eşlik eden katatoninin yüksek doz parenteral benzodiazepin tedavisine hızlı cevap verdiği, ilk benzodiazepin dozundan veya ikinci dozdan birkaç saat sonra çoğu olguda katatoni tablosunun düzeldiği, ancak bazı olgularda bu düzelmenin haftalar hatta aylar sonra olabileceği belirtilmektedir.4 Olgumuzda da altta yatan tanının bir duygudurum bozukluğu olması ve yüksek doz diazepam ile belirtilerin hızlı düzelmesi literatürdeki verilerle uyumludur. Ancak benzodiazepin olarak en çok veri lorazepam ile ilgili olmasına rağmen olgumuz diazepam tedavisi ile düzelmiştir.

Katatoni, akut psikiyatri servislerine başvuran çocuk ve ergenlerde nadir bir durum 
değildir ve ayırıcı tanıda akla gelmelidir. DSM5 'te katatoninin ayrı bir başlık olarak yer alması bu tablonun klinisyenler tarafından tanınma oranını arttıracak gibi görünmektedir. Katatoni tablosu ile başvuran çocuk ve gençlerde lorazepam ve EKT dışında diğer bir seçenek olan diazepamın tedavide göz önünde bulundurulması gerekir. Ayrıca duygudurum bozukluklarıla katatoni tablosu birlikteliğinin sıklığı dikkate alındığında, katatoni tablosu düşünülen olgularda, duygudurum bozukluklarına yönelik öykünün ayrıntılı olması takip ve tedavi sürecinde yararlı olacaktır.

\section{KAYNAKLAR}

1. Daniels J. Catatonia: clinical aspects and neurobiologi- cal correlates. J Neuropsychiatry Clin Neurosci 2009; 21:371-380.2. Beidel DC, Turner SM. Childhood Anxiety Disorder: a guide to research and treatment. Newyork: Taylor\&Francis; 2005. p. 188.

2. APA. Diagnostic and Statistical Manual of Mental Dis- orders. 5ed. Arlington: American Psychiatric Associa- tion; 2013.4. Türkbay T, Söhmen T. Ayrılık kaygısı bozukluğunda bireysel ve ailesel etmenler. Turk J Child Adolesc Ment Health 2001; 8: 77-84.

3. Taylor MA, Fink M. Catatonia in psychiatric classi- fication: A home of its own. Am J Psychiatry 2003; 160:1233-1241.6. Özcan Ö, Kılıç BG, Aysev A. Okul korkusu yakınması olan çocukların ana babalarında ruhsal bozukluklar. Türk Psikiyatri Dergisi 2006; 17: 173180.

4. Rosebush PI, Mazurek MF. Catatonia and its treat- ment. Schizophr Bull 2010; 36:239-242.

5. Paparrigopoulos $T$, Tzavellas E, Ferentinos $P$, Mourikis I, Liappas J. Catatonia as a risk factor for the develop- ment of neuroleptic malignant syndrome: report of a case following treatment with clozapine. World J Biol Psychiatry 2009; 10:70-73.

6. Pfister HW, Preac-Mursic V, Wilske B, Rieder G, Förder- reuther S, Schmidt S, Kapfhammer HP. Catatonic syndrome in acute severe encephalitis due to Borrelia burgdorferi infection. Neurology 1993; 43: 433-435.
7. Kalivas KK, Bourgeois JA. Catatonia after liver and kid- ney transplantation. Gen Hosp Psychiatry 2009; 31: 196-198.

8. Shepherd J, Garza VM, De Leon OA. Waxingand-wan- ing catatonia after intermittent exposure to aripipra- zole in a case of autism and bipolar disorder. J Clin Psychopharmacol 2009; 29: 503-504

9. Ghaziuddin N, Gih D, Barbosa V, Maixner DF, Ghazi- uddin M. Onset of catatonia at puberty: electrocon- vulsive therapy response in two autistic adolescents. J ECT 2010; 26: 274-277.

10. Dhossche DM, Reti IM, Wachtel LE. Catatonia and au-tism: a historical review, with implications for electro- convulsive therapy. J ECT 2009; 25: 19-22. 